\title{
Aktivitas Antihiperlipidemia Ekstrak Buah Okra (Abelmoschus esculentus (L.) Moench) pada Tikus yang Diinduksi Emulsi Lemak
}

\section{Antidyslipidemic Activity of Okra (Abelmoschus esculentus (L.) Moench) Fruit Extract in Fat Induced-Rats}

\author{
Widhya Aligita*, Dulce De Sousa Tpoy, Elis Susilawati \\ Departemen Farmakologi, Fakultas Farmasi, Universitas Bhakti Kencana \\ Jl. Soekarno Hatta No 754, Bandung, Jawa Barat, Indonesia \\ *Corresponding author email: widhya.aligita@bku.ac.id
}

Received 06-12-2019 Accepted 23-06-2020 Available online 01-07-2020

\begin{abstract}
ABSTRAK
Hiperlipidemia merupakan salah satu faktor penyakit kardiovaskular dengan angka kematian di dunia cukup tinggi. Buah okra (Abelmoschus esculentus (L.) Moench) merupakan salah satu sayuran yang berpotensi dapat digunakan sebagai antihiperlipidemia. Tujuan dari penelitian ini untuk mengetahui efek antihiperlipidemia dan dosis optimal dari ekstrak air buah okra pada tikus galur wistar yang diinduksi emulsi lemak. Tikus putih jantan galur wistar berumur 2-3 bulan dengan bobot 150-200 gram dibagi secara merata menjadi 6 kelompok yang terdiri dari kelompok kontrol negatif, kelompok kontrol positif, kelompok simvastatin $10 \mathrm{mg} / \mathrm{kg} \mathrm{BB}$, kelompok ekstrak air buah okra dosis 50, 100, dan $200 \mathrm{mg} / \mathrm{kg} \mathrm{BB}$. Induksi hiperlipidemia dilakukan dengan pemberian emulsi lemak. Perlakuan dilakukan selama 35 hari. Parameter yang diukur adalah kadar kolesterol total, trigliserida, dan low-density lipoprotein (LDL). Berdasarkan hasil pengukuran kolesterol total, trigliserida, dan LDL, dapat dilihat bahwa pemberian ekstrak air buah okra dengan dosis 100 dan $200 \mathrm{mg} / \mathrm{kg}$ BB mampu menurunkan kadar kolesterol total, trigliserida, dan LDL secara signifikan dibandingkan dengan kelompok kontrol positif. Ekstrak air buah okra pada dosis $100 \mathrm{mg} / \mathrm{kg} \mathrm{BB}$ memiliki aktivitas dalam menurunkan kadar kolesterol total, trigliserida, dan LDL.
\end{abstract}

Kata kunci: Abelmoschus esculentus, hiperlipidemia, kolesterol, trigliserida.

\begin{abstract}
Hyperlipidemia is a factor of cardiovascular diseases with a high mortality rate worldwide. Okra (Abelmoschus esculentus (L.) Moench) fruit is potentially used as an antihyperlipidemic agent. The aim of this study was to determine the antihyperlipidemic effect of water extract of okra fruit on fat emulsion-induced rats. Male white rats of 2-3 months old Wistar strain weighing 150-200 grams were divided randomly into 6 groups,
\end{abstract}


i.e., negative control, positive control, $10 \mathrm{mg} / \mathrm{kg}$ BW simvastatin, okra fruit water extract group dose of 50,100, and $200 \mathrm{mg} / \mathrm{kg} \mathrm{BW}$, respectively. Hyperlipidemia was induced by fat emulsion administration. The treatment was carried out for 35 days. The parameters measured were total cholesterol, triglycerides, and low-density lipoprotein (LDL) levels. Okra fruit extract at doses of 100 and $200 \mathrm{mg} / \mathrm{kg} \mathrm{BW}$ significantly reduced cholesterol, triglycerides, and LDL levels compared to those of the positive control group. Okra fruit water extract at a dose of $100 \mathrm{mg} / \mathrm{kg}$ BW showed total cholesterol, triglycerides, and LDL levels reduction activities.

Key words: Abelmoschus esculentus, hyperlipidemia, cholesterol, triglyseride.

\section{Pendahuluan}

Dislipidemia

merupakan

gangguan metabolik yang ditandai dengan ketidaknormalan kadar lipid dalam darah, meliputi peningkatan kadar kolesterol atau trigliserida, atau keduanya, atau penurunan HDL (High Density Lipoprotein) (Adetuyi dan Osagie, 2011). Dislipidemia seringkali dihubungkan dengan gejala sindrom metabolik lain seperti hipertensi (Krishna et al., 2016), diabetes (Schofield et al., 2016), aterosklerosis (Garg et al., 2015), dan penyakit kardiovaskular (Miller, 2009).

Berdasarkan data The World Health Organization tahun 2015, pada tahun 2012, sebanyak 17,5 juta orang meninggal disebabkan penyakit kardiovaskular. Dari kematian ini, diperkirakan 7,4 juta adalah karena penyakit jantung koroner dan 6,7 juta adalah stroke, dan angka ini diperkirakan akan terus meningkat mencapai 23,3 juta pada tahun 2030.

Pengobatan dan pencegahan hiperlipidemia dapat dilakukan dengan terapi farmakologi dan nonfarmakologi. Terapi nonfarmakologi dapat dilakukan dengan beberapa cara, secara umum dengan merubah pola hidup yang lebih baik seperti terapi nutrisi medis, diet seimbang dengan rencana makan yang seimbang, menjaga berat badan, pembatasan kalori, dan olahraga. Sedangkan untuk terapi farmakologi, terdapat beberapa golongan obat yang biasa digunakan, salah satunya adalah golongan statin (simvastatin). Namun seperti obat-obatan lain, golongan statin memiliki beberapa efek samping (Golomb dan Evans, 2008). Karena itu diperlukan alternatif pengobatan yang lebih aman namun tetap efektif. Terapi nutrisi (nutrition therapy) merupakan salah satu solusi yang dapat digunakan sebagai salah satu alternatif untuk menjaga kadar lipid tetap terjaga di nilai normal.

Salah satu sayuran yang berpotensi digunakan sebagai terapi nutrisi untuk penderita hiperlipidemia adalah buah okra (Gambar 1). Okra, yang memiliki nama latin Abelmoschus esculentus (L.) Moench dan termasuk ke dalam family Malvaceae, biasa dimanfaatkan sebagai sayuran (Adetuyi dan Osagie, 2011). Tanaman okra diduga berasal dari Afrika Selatan, India, atau Asia Tenggara (Siemonsma, 1982). 
Secara tradisional, okra telah lama digunakan untuk pengobatan seperti di pengobatan Ayurveda, Siddha, dan Unani (Nilesh et al., 2012). Kandungan musilago yang tinggi dari buahnya akan memberikan tekstur berlendir ketika dimasak. Selain itu, buah okra juga kaya akan vitamin, mineral, serat, dan karbohidrat (Adetuyi dan Osagie, 2011; Gemede et al., 2016). Beberapa penelitian sebelumnya menunjukkan bahwa buah okra memiliki aktifitas dalam menurunkan kadar kolesterol total, trigliserida, LDL, dan meningkatkan kadar HDL (Huynh et al., 2008; Sabitha et al., 2011; Dugani et al., 2018). Berdasarkan data tersebut, maka penelitian ini bertujuan untuk mengevaluasi aktivitas antihiperlipidemia dari ekstrak air buah okra.

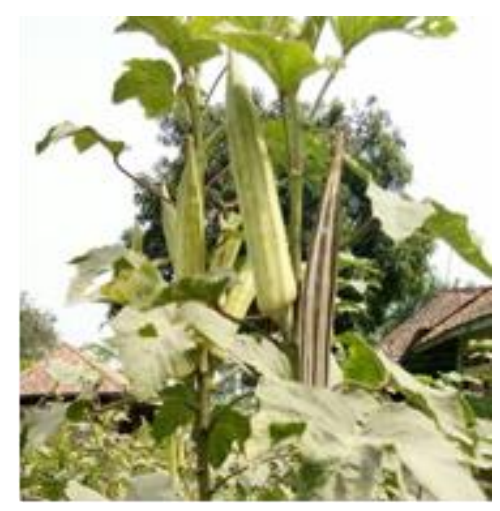

Gambar 1. Buah okra.

\section{Metode Penelitian}

\section{Bahan Tumbuhan}

Bahan yang digunakan dalam penelitian ini adalah buah okra dengan nama latin Abelmoschus esculentus (L.) Moench yang diperoleh dari Badan Penelitian Tanaman Rempah dan Obat (Balitro) Kota Bogor, Jawa Barat. Proses determinasi dilakukan untuk memastikan kebenaran tanaman yang akan digunakan sebagai bahan penelitian. Determinasi buah okra dilakukan di Pusat Konservasi Tumbuhan Kebun Raya Lembaga IImu Pengetahuan
Indonesia (PKT Kebun Raya LIPI), dengan nomor B-3807/IPH.3./KS/XII/2017.

\section{Jalannya Penelitian}

1. Pembuatan ekstrak air buah okra

Pembuatan ekstrak buah okra dilakukan dengan cara dingin yaitu dengan cara dijus menggunakan pelarut air. Kemudian hasil jusan diperas menggunakan kain batis sehingga diperoleh filtrat. Filtrat kemudian dipekatkan menggunakan freeze dryer dan didapat ekstrak air buah okra dalam bentuk serbuk (Depkes RI, 2000). 
2. Uji aktivitas antihiperlipidemia

Penelitian ini menggunakan true experimental yang dilakukan secara in vivo. Hewan uji yang digunakan dalam penelitian ini adalah tikus putih jantan galur Wistar yang berumur 2-3 bulan, dengan bobot 200-250 gram dengan kondisi badan sehat (aktif dan tidak cacat). Hewan uji diperoleh dari D'Wistar (penyedia hewan laboratorium), Majalaya, Bandung Jawa Barat, dan mendapat persetujuan dari Komisi Etik Penelitian, Fakultas Kedokteran, Universitas Padjajaran dengan Nomor 246/UN6.KEP/EC/2018.

Tikus jantan diaklimatisasi selama 7 hari dan kemudian diukur kadar lipid darah awalnya (TO). Tikus dibagi dalam 6 kelompok yaitu kelompok kontrol negatif, kelompok kontrol positif, kelompok simvastatin $10 \mathrm{mg} / \mathrm{kg}$ BB, kelompok ekstrak air buah okra (EABO) $50 \mathrm{mg} / \mathrm{kg} \mathrm{BB}$, kelompok EABO $100 \mathrm{mg} / \mathrm{kg} \quad \mathrm{BB}$, kelompok EABO $200 \mathrm{mg} / \mathrm{kg}$ BB. Perlakuan dilakukan selama 35 hari, dan parameter yang diukur adalah kadar kolesterol darah total, trigliserida, dan kolesterol-LDL pada saat sebelum perlakuan (TO) dan pada akhir perlakuan (T35). Induksi hiperlipidemia dilakukan dengan pemberian emulsi lemak (Supkamonseni et al., 2014).

3. Analisis data

Data yang didapat dianalisis menggunakan One-Way Anova.

\section{Hasil dan Pembahasan}

Hasil karakterisasi ekstrak ditunjukkan oleh Tabel 1. Hasil skrining fitokimia ekstrak menunjukkan hasil positif terhadap flavonoid dan steroid/triterpenoid.

Tabel 1. Hasil karakterisasi ekstrak

\begin{tabular}{lc}
\hline \multicolumn{1}{c}{ Parameter } & Hasil Pengukuran (\% b/b) \\
\hline Abu total & 14 \\
Sari larut air & 72 \\
Sari larut etanol & 39 \\
Susut pengeringan & 5,39 \\
Kadar air & $9,69 \% \mathrm{v} / \mathrm{b}$ \\
\hline
\end{tabular}

Aktivitas antihiperlipidemia dari ekstrak air buah okra ditunjukkan dengan perubahan kadar profil lipid dalam darah yang meliputi kadar kolesterol total, trigliserida, dan kolesterol LDL antara sebelum dan setelah perlakuan. Hasil pengukuran kadar kolesterol total pada saat sebelum dan setelah 35 hari pemberian ekstrak air buah okra ditunjukkan oleh Tabel 2 .

Kadar kolesterol total kelompok kontrol positif mengalami kenaikan yang 
signifikan secara statistik jika dibandingkan dengan kelompok kontrol negatif seperti yang ditunjukkan oleh Tabel 2. Hal ini menunjukkan bahwa pemberian emulsi lemak selama 35 hari mampu meningkatkan kadar kolesterol total pada hewan uji. Pada kelompok yang diberikan perlakuan, baik dengan simvastatin ataupun ekstrak air buah okra dengan variasi dosis, mengalami penurunan kadar kolesterol total; walaupun hanya kelompok simvastatin, ekstrak air buah okra dosis $100 \mathrm{mg} / \mathrm{kg}$ $\mathrm{BB}$, dan dosis $200 \mathrm{mg} / \mathrm{kg}$ BB yang menunjukkan kadar yang lebih rendah secara signifikan dibandingkan dengan kelompok kontrol positif $(p<0,05)$. Sedangkan jika dibandingkan dengan kelompok simvastatin, hanya kelompok ekstrak air buah okra dosis $100 \mathrm{mg} / \mathrm{kg}$ BB dan $200 \mathrm{mg} / \mathrm{kg}$ BB saja yang menunjukkan aktivitas yang sebanding dalam menghambat kenaikan kadar kolesterol total.

Tabel 2. Kadar kolesterol total

\begin{tabular}{lccc}
\hline \multicolumn{1}{c}{ Kelompok } & \multicolumn{2}{c}{ Kadar Kolesterol Total pada Hari ke- (mg/dl) } & \multicolumn{1}{c}{$\begin{array}{c}\text { Persentase } \\
\text { Perubahan (\%) }\end{array}$} \\
\cline { 2 - 3 } & $\mathbf{0}$ & $\mathbf{3 5}$ & -19 \\
\hline Kontrol negatif & $76,32 \pm 4,20$ & $62 \pm 3,12^{*}$ & 60 \\
Kontrol positif & $66,3 \pm 12,89$ & $106,2 \pm 54,15 \#$ & 11 \\
Simvastatin $10 \mathrm{mg} / \mathrm{kg} \mathrm{BB}$ & $65,16 \pm 2,62$ & $72,73 \pm 16,45^{*}$ & 2 \\
EABO $50 \mathrm{mg} / \mathrm{kg} \mathrm{BB}$ & $76,35 \pm 15,98$ & $78,15 \pm 23,22$ & 28 \\
EABO $100 \mathrm{mg} / \mathrm{kg} \mathrm{BB}$ & $48,8 \pm 6,96$ & $62,72 \pm 16,30^{*}$ & 19 \\
EABO $200 \mathrm{mg} / \mathrm{kg} \mathrm{BB}$ & $72,27 \pm 14,08$ & $58,72 \pm 15,26^{*}$ & 28 \\
\hline
\end{tabular}

Keterangan: data dipresentasikan dalam bentuk rata-rata $\pm S D ; n=5 ;{ }^{*}=$ berbeda bermakna jika dibandingkan dengan kelompok kontrol positif $(p<0,05)$; \# = berbeda bermakna jika dibandingkan dengan kelompok simvastatin $(p<0,05)$.

Hasil pengukuran kadar trigliserida pada saat sebelum dan setelah 35 hari pemberian ekstrak air buah okra ditunjukkan oleh Tabel 3 . Kadar trigliserida kelompok kontrol positif mengalami kenaikan yang signifikan secara statistik jika dibandingkan dengan kelompok kontrol negatif. Hal ini menunjukkan bahwa pemberian emulsi lemak selama 35 hari mampu meningkatkan kadar trigliserida pada hewan uji.
Pada kelompok yang diberikan perlakuan, baik dengan simvastatin ataupun ekstrak air buah okra dengan 3 variasi dosis, mengalami penurunan kadar trigliserida; walaupun hanya kelompok simvastatin, ekstrak air buah okra dosis 100 mg/kg BB, dan dosis 200 $\mathrm{mg} / \mathrm{kg}$ BB yang menunjukkan kadar trigliserida yang lebih rendah secara signifikan dibandingkan dengan kelompok kontrol positif $(p<0,05)$. Sedangkan jika dibandingkan dengan 
kelompok simvastatin, hanya kelompok ekstrak air buah okra dosis $100 \mathrm{mg} / \mathrm{kg}$ BB dan $200 \mathrm{mg} / \mathrm{kg} \quad B B$ saja yang menunjukkan aktivitas yang sebanding dalam menghambat kenaikan kadar trigliserida.

Tabel 3. Kadar trigliserida

\begin{tabular}{lccc}
\hline \multirow{2}{*}{ Kelompok } & \multicolumn{2}{c}{ Kadar Trigliserida pada Hari ke- (mg/dl) } & $\begin{array}{c}\text { Persentase } \\
\text { Perubahan (\%) }\end{array}$ \\
\cline { 2 - 3 } & $\mathbf{0}$ & $\mathbf{3 5}$ & -28 \\
Kontrol negatif & $69,45 \pm 20,95$ & $49,7 \pm 16,68^{*}$ & 75 \\
Kontrol positif & $58,35 \pm 19,66$ & $102,27 \pm 66,4 \#$ & -22 \\
Simvastatin $10 \mathrm{mg} / \mathrm{kg} \mathrm{BB}$ & $69,7 \pm 12,32$ & $54,45 \pm 15,23^{*}$ & 5 \\
EABO $50 \mathrm{mg} / \mathrm{kg} \mathrm{BB}$ & $73,4 \pm 53,3$ & $77 \pm 30,54$ & -38 \\
EABO $100 \mathrm{mg} / \mathrm{kg} \mathrm{BB}$ & $81,45 \pm 14,47$ & $50,12 \pm 5,85^{*}$ & -22 \\
EABO $200 \mathrm{mg} / \mathrm{kg} \mathrm{BB}$ & $70,07 \pm 23,02$ & $54,37 \pm 9,14^{*}$ & \\
\hline
\end{tabular}

Keterangan: data dipresentasikan dalam bentuk rata-rata $\pm S D ; n=5 ;{ }^{*}=$ berbeda bermakna jika dibandingkan dengan kelompok kontrol positif $(p<0,05)$; \# = berbeda bermakna jika dibandingkan dengan kelompok simvastatin $(p<0,05)$.

Hasil pengukuran kadar kolesterol-LDL pada saat sebelum dan setelah 35 hari pemberian ekstrak air buah okra ditunjukkan oleh Tabel 4 . Kadar kolesterol-LDL kelompok kontrol positif mengalami kenaikan yang signifikan secara statistik jika dibandingkan dengan kelompok kontrol negatif. Hal ini menunjukkan bahwa pemberian emulsi lemak selama 35 hari mampu meningkatkan kadar kolesterolLDL pada hewan uji. Pada kelompok yang diberikan perlakuan, baik dengan simvastatin ataupun ekstrak air buah okra dengan 3 variasi dosis, mengalami penurunan kadar kolesterol-LDL; walaupun hanya kelompok simvastatin, ekstrak air buah okra dosis $100 \mathrm{mg} / \mathrm{kg}$ $\mathrm{BB}$, dan dosis $200 \mathrm{mg} / \mathrm{kg}$ BB yang menunjukkan kadar kolesterol-LDL yang lebih rendah secara signifikan dibandingkan dengan kelompok kontrol positif $(p<0,05)$. Sedangkan jika dibandingkan dengan kelompok simvastatin, hanya kelompok ekstrak air buah okra dosis $100 \mathrm{mg} / \mathrm{kg}$ BB dan 200 $\mathrm{mg} / \mathrm{kg} \quad B B$ saja yang menunjukkan aktivitas yang sebanding dalam menghambat kenaikan kadar kolesterolLDL.

Penelitian ini bertujuan untuk mengevaluasi aktivitas antihiperlipidemia dari ekstrak air buah okra. Berdasarkan hasil pengukuran kolesterol total, trigliserida, dan LDL, dapat dilihat bahwa pemberian ekstrak air buah okra dengan dosis $100 \mathrm{mg} / \mathrm{kg}$ BB dan $200 \mathrm{mg} / \mathrm{kg}$ BB mampu menurunkan kadar lipid secara signifikan dibandingkan dengan kelompok kontrol positif. Aktifitas antihiperlipidemia pada kedua dosis ini dapat dikatakan setara 
dengan aktivitas simvastatin sebagai obat standar hiperlipidemia, ditandai dengan tidak adanya perbedaan bermakna secara statistik jika dibandingkan dengan kelompok simvastatin. Aktivitas antihiperlipidemia ini tidak lepas dari kandungan senyawa yang ada di dalam ekstrak air buah okra. Berdasarkan hasil skrining fitokimia, ekstrak air buah okra mengandung golongan senyawa flavonoid dan steroid/triterpenoid.
Buah okra mengandung 67,50\% $\alpha$-selulosa; $15,40 \%$ hemiselulosa; 7,10\% lignin; 3,40\% komponen peptic; 3,90\% komponen lemak dan lilin, serta 2,70\% air (Kumar et al., 2013). Hemiselulosa dan $\alpha$-selulosa termasuk ke dalam golongan serat dan dietary fiber. Serat dapat menurunkan kadar kolesterol total dan LDL dan dapat menurunkan respon hiperglikemik (menekan kenaikan gula darah sesudah makan) (Desthia dan Yuniarni, 2015).

Tabel 4. Kadar LDL

\begin{tabular}{lccc}
\hline \multirow{2}{*}{ Kelompok } & \multicolumn{2}{c}{ Kadar LDL pada Hari ke- $(\mathbf{m g} / \mathrm{dl})$} & \multirow{2}{*}{ Persentase Perubahan (\%) } \\
\cline { 2 - 3 } & $\mathbf{0}$ & $\mathbf{3 5}$ & 36 \\
\hline Kontrol negatif & $18,52 \pm 6,04$ & $25,3 \pm 2,84^{*} \#$ & 40 \\
Kontrol positif & $26,47 \pm 6,24$ & $37,12 \pm 16,80 \#$ & -26 \\
Simvastatin $10 \mathrm{mg} / \mathrm{kg}$ BB & $25,25 \pm 6,64$ & $18,57 \pm 1,56^{*}$ & 9 \\
EABO $50 \mathrm{mg} / \mathrm{kg} \mathrm{BB}$ & $22 \pm 8,19$ & $27,62 \pm 2,19$ & 23 \\
EABO $100 \mathrm{mg} / \mathrm{kg} \mathrm{BB}$ & $21,22 \pm 1,49$ & $26,05 \pm 2,02^{*}$ & 18 \\
\hline
\end{tabular}

Ket: data dipresentasikan dalam bentuk rata-rata $\pm S D ; n=5 ;{ }^{*}=$ berbeda bermakna jika dibandingkan dengan kelompok kontrol positif $(p<0,05)$; \# = berbeda bermakna jika dibandingkan dengan kelompok simvastatin $(p<0,05)$.

Berdasarkan hasil penapisan fitokimia, ekstrak air buah okra yang digunakan dalam pengujian mengandung flavonoid dan steroid/triterpenoid. Kandungan flavonoid dari buah okra memiliki pengaruh terhadap kadar profil lipid dengan cara memperbaiki fungsi endotel pembuluh darah, dapat mengurangi kepekaan LDL sehingga dapat menurunkan kadar kolesterol total, trigliserida, serta meningkatkan HDL dengan menghambat enzim HMG CoA reductase (Sumardika dan Jawi, 2011). Flavonoid juga mampu mengaktifkan sistem multi enzim yaitu sitokrom $\mathrm{p}-450$ dan b5 yang mempunyai fungsi mengikat kadar kolesterol dan cairan empedu untuk dieksresikan (Kwon et al., 2015). Penelitian lain menunjukkan bahwa flavonoid memiliki aktivitas dalam menurunkan lipogenesis hati dan absorpsi lipid (Kwon et al., 2015; Jung et al., 2016; Hoek-van den Hil et al., 2015). 


\section{Simpulan}

Ekstrak air buah okra pada dosis 100 mg/kg BB memiliki aktivitas dalam menurunkan kadar kolesterol total, trigliserida, dan LDL menjadi $62,72 \pm 16,30 ; \quad 50,12 \pm 5,85 ; \quad$ dan $26,05 \pm 2,02$; berturut-turut.

\section{Daftar Pustaka}

Adetuyi, F., Osagie, A. 2011. Nutrient, antinutrient, mineral and zinc bioavailability of okra Abelmoschus esculentus (L) Moench variety. American Journal of Food and Nutrition, 1(2):49-54.

Departemen Kesehatan RI. 2000. Parameter Standar Umum Ekstrak Tumbuhan Obat. Jakarta: Direktorat Jenderal Pengawasan Obat dan Makanan, Direktorat Pengawasan Obat Tradisional, Departemen Kesehatan Republik Indonesia.

Desthia, U.M., Yuniarni, U. 2015. Uji Aktivitas Hipoglikemik Ekstrak Etanol Daun Okra (Abelmoschus esculentus (L). Moench) pada Mencit Jantan Galur Swiss Webster dengan Metode Toleransi Glukosa Oral. Prosiding penelitian SPeSIA, 1(1):115-120.

Dugani, A.M., Alkhetally, W.I., Elghedafi, E.O., Alkayed, F.W. 2018. Effects of the aqueous extract from Abelmoschus esculentus $\mathrm{L}$ peel on hyperglycemia and hyperlipidemia induced by dexamethasone in rats. Libyan International Medical University Journal, 3(1):3-7.
Garg, R., Aggarwal, S., Kumar, R., Sharma, G. 2015. Association of atherosclerosis with dyslipidemia and co-morbid conditions: a descriptive study. Journal of Natural Science, Biology, and Medicine, 6(1):163168.

Gemede, H.F., Haki, G.D., Beyene, F., Woldegiorgis, A.Z., Rakshit, S.K. 2016. Proximate, mineral, and antinutrient compositions of indigenous okra (Abelmoschus esculentus) pod accessions: Implications for mineral bioavailability. Food Science and Nutrition, 4(2):223-233.

Golomb, B.A., Evans, M.A. 2008. Statin adverse effects: a review of the literature and evidence for a mitochondrial mechanism. American Journal of Cardiovascular Drugs, 8(6):373418.

Hoek-van den Hil, E.F, van Schothorst, E.M., van der Stelt, I., Swarts, H.J., van Vliet, M., Amolo, T., Vervoort, J.J., Venema, D., Hollman, P.C., Rietjens, I.M., Keijer, J. 2015. Direct comparison of metabolic health effects of the flavonoids quercetin, hesperetin, epicatechin, apigenin and anthocyanins in high-fat-diet-fed mice. Genes Nutrition, 10(4):23.

Huynh Ngoc, T., Nguyen Ngoc, Q., Tran, T., Van, A., Vo Phung, N. 2008. Hypolipidemic effect of extracts from Abelmoschus esculentus $\mathrm{L}$. (Malvaceae) on tyloxapolinduced hyperlipidemia in mice. Mahidol University Journal of 
Pharmaceutical Sciences, 35(14):42-46.

Jung, U.J., Cho, Y.Y., Choi, M.S. 2016. Apigenin ameliorates dyslipidemia, hepatic steatosis and insulin resistance by modulating metabolic and transcriptional profiles in the liver of high-fat diet-induced obese mice. Nutrients, 8:305.

Krishna, T.V.M., Vasa, V.K., Ponnuru, V.A.D. 2016. The study of correlation between dyslipidemia and hypertension and its complications in $30-70$ years age group. International Archives of Integrated Medicine, 3(4):84-90.

Kumar, D.S., Tony, D.E., Kumar, A.P., Kumar, K.A., Srinivasa, Rao, D.B., Nadendla, R. 2013. A review on: Abelmoschus esculentus (okra). International Research Journal of Pharmaceutical and Applied Sciences, 3(4):129-132.

Kwon, E.Y., Jung, U.J., Park, T., Yun, J.W., Choi, M.S. 2015. Luteolin attenuates hepatic steatosis and insulin resistance through the interplay between the liver and adipose tissue in mice with dietinduced obesity. Diabetes, 64:1658-1669.

Miller, M. 2009. Dyslipidemia and cardiovascular risk: the importance of early prevention. QJM, 102(9):657-667.
Nilesh, J., Jain, R., Jain, V.J.S. 2012. A review on: Abelmoschus esculentus. PHARMACIA, 1(3):18.

Sabitha, V., Ramachandran, S., Naveen, K.R., Panneerselvam, R. 2011. Antidiabetic and antihyperlipidemic potential of Abelmoschus esculentus (L.) Moench. Journal of Pharmacy \& BioAllied Sciences, 3(3):379-402.

Schofield, J.D., Liu, Y., Rao-Balakrishna, P., Malik, R.A., Soran, H. 2016. Diabetes dyslipidemia. Diabetes Therapy, 7(2):203-219.

Siemonsma, J.S. 1982. West african okra-morphological and cytogenetical indications for the existence of a natural amphidiploid of Abelmoschus esculentus (L.) Moench and A. manihot (L.) Medikus. Euphytica, 31(1): 241-252.

Sumardika, I.W., Jawi, I.M. 2011. Ekstrak air daun ubijalar ungu memperbaiki profil lipid dan meningkatkan kadar SOD darah tikus yang diberi makanan tinggi kolesterol. Jurnal IImiah Kedokteran, 43(2):67-70.

Supkamonseni, N., Thinkratok, A., Meksuriyen, D., Srisawat, R. 2014. Hypolipidemic and hypoglycemic effects of Centella asiatica (L.) extract in vitro and in vivo. Indian Journal of Experimental Biology, 52:965971. 